\title{
Implications of sudden oak death for wildland fire management
}

\author{
Margaret R. Metz ${ }^{1}$, J. Morgan Varner ${ }^{2}$, Allison B. Simler ${ }^{3}$, Kerri M. Frangioso ${ }^{3}$, and David M. Rizzo ${ }^{3}$ \\ ${ }^{1}$ Department of Biology, Lewis \& Clark College, Portland, OR 97219; ${ }^{2}$ Pacific Wildland Fire Sciences \\ Laboratory, 400 N. 34th St., Suite 201, Seattle, WA 98103; ${ }^{3}$ Department of Plant Pathology, One Shields \\ Avenue, University of California, Davis, CA 95616. Corresponding author: mmetz@Iclark.edu
}

\begin{abstract}
Human activities and climate change have altered historical disturbance regimes, introduced disturbances, and encouraged novel interactions between multiple disturbances. Ecosystems and the species that comprise them may be poorly equipped to withstand or recover from these altered disturbance regimes. In the fire-prone coastal forests of California and Oregon, sudden oak death (SOD), caused by the pathogen Phytophthora ramorum, is an emerging, non-native plant disease that causes widespread tree mortality and associated implications for fire regimes. Disease-related tree mortality alters fuel loads, with patterns of fuel accumulation varying depending on stand composition, disease severity, and time since pathogen invasion. Simulations and observational studies suggest these altered fuel profiles can impact subsequent fire behavior, and the extent of this interaction may depend on the severity and timing of disease impacts. Initial tree death can elevate the risk of crown ignition, while latter stages can increase surface fuel loading and have been linked to increased fire severity in wildfires. Further, disease history can also influence fire severity with cascading effects leading to unexpected increases in mortality of nonsusceptible tree species and changes in nutrient cycling. The longer-term impacts of SOD-fire interactions on system resilience and recovery remain to be seen, but increased fire severity, changed stand structure, and altered biogeochemical cycling may have important consequences for post-fire regeneration and future ecosystem function. Fuels management strategies that diminish crown fire hazards at early stages and mitigate surface fuel hazards at later stages offer some promise, but have yet to be tested in large landscapes. Given SOD-wildfire interactions, further integration of disease- and fire-related management plans will be essential to minimizing impacts of these compounded disturbances.
\end{abstract}

\section{Introduction}

Ecosystems are experiencing new or altered disturbances as a result of species introductions, changing land use, a warming climate, or other aspects of global change (Aukema et al. 2010; Ellison et al. 2005; Johnstone et al. 2016; Turner 2010). The effects of one disturbance can alter the risk or impact of a subsequent disturbance, with important implications for ecosystem structure and composition. Species are often adapted to the historical disturbance regime in an ecosystem, and their traits may be poorly suited to disturbances of differing severity, frequency, or type, especially when they co-occur with changing climatic conditions (Johnstone et al. 2016). Altered disturbances and novel interactions may slow the pace or extent of post-disturbance recovery, favor particular species that are better adapted to the disturbance, or lead to large-scale shifts in composition or structure. The potential for multiple interacting components of global change to alter disturbance regimes or compromise ecosystem resilience is a relatively understudied aspect of global change but one with increasingly pressing consequences for land managers and communities in the wildland-urban interface (Johnstone et al. 2016; Turner 2010).

The coastal forests of central and northern California, USA have provided an important opportunity to study potential interactions among multiple disturbances and their consequences for land managers. Fire frequency or severity are increasing in many systems across the western US, driven largely by warming temperatures, fire suppression policies, increased aridity, and human sources of ignition (Steel, Safford, 
and Viers 2015; Stephens and Ruth 2005; Westerling et al. 2006). Large swaths of California coastal forests have been invaded by the introduced plant pathogen Phytophthora ramorum Werres, de Cock \& Man in't Veld, which causes the emerging forest disease sudden oak death (hereafter "SOD") (Rizzo and Garbelotto 2003). Phytophthora ramorum kills tanoak (Notholithocarpus densiflorus (Hook. \& Arn.) Manos, Cannon \& S. Oh and several species of true oaks (Quercus spp.) in the coniferous or mixedevergreen forests stretching north from San Luis Obispo County across the Oregon border. P. ramorumkilled trees, particularly large ones, remain standing after death for several years before falling, and this has led to increasing accumulations of fuels over time in fire-prone forests (Cobb and Rizzo 2012; Forrestel et al. 2015). The pathogen's contribution to increased fuel loading has given rise to worries that SOD will influence wildfire behavior, severity and extent in a novel disturbance interaction, and, by doing so, endanger communities, increase the costs and risks of fighting fires, and alter forest and woodland ecosystems (Figure 1). In 2008, the first large wildfires occurred in SOD-impacted landscapes, including large fires in Big Sur, California, one of the earliest sites of $P$. ramorum invasion and one of the most heavily impacted regions. Here we review existing field-based pre- and post-fire studies of disease impacts combined with other laboratory and modeling research to address potential interactions of sudden oak death and wildfire and the consequences of those interactions for land management.

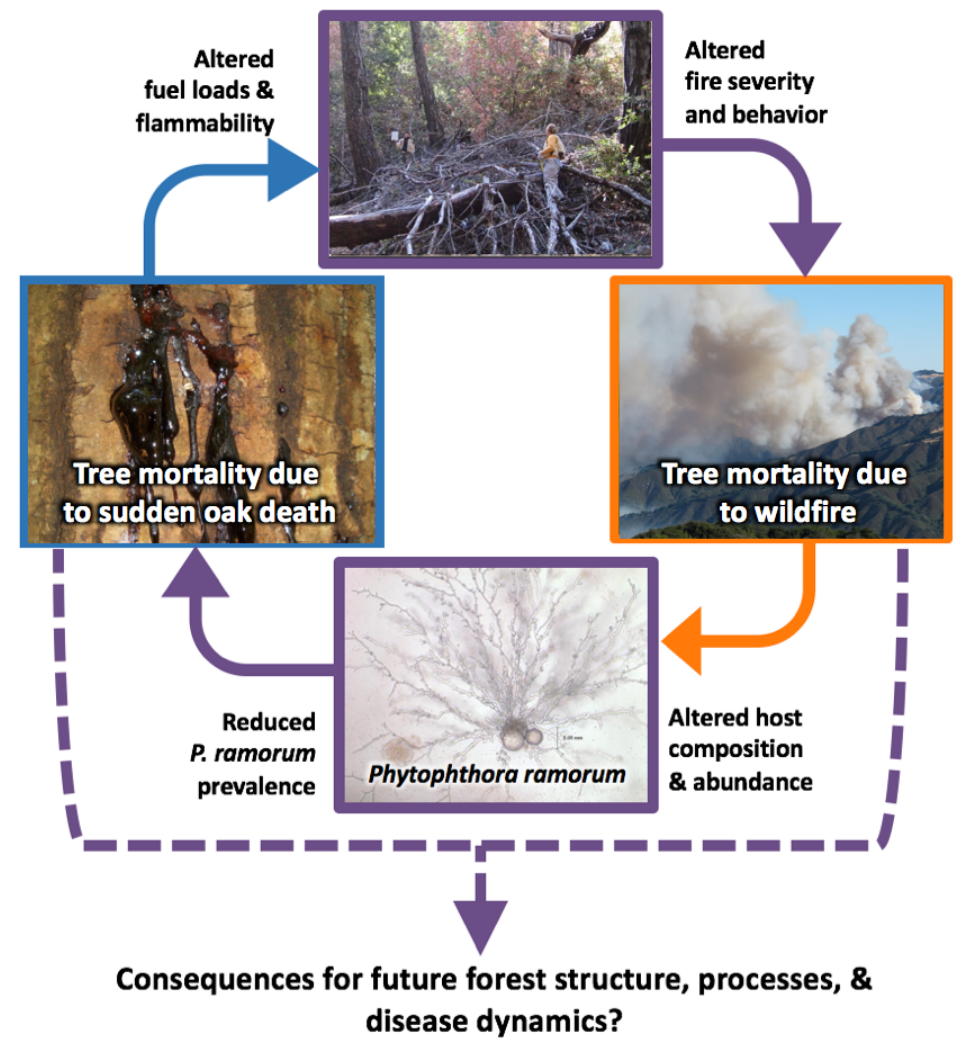

Figure 1. Conceptual diagram of potential interactions between sudden oak death and wildfire. Solid lines indicate direct effects of either disturbance on forest characteristics; dashed arrows indicate the interactive effects of both disturbances for forest and disease dynamics. Photos courtesy of the Rizzo lab at UC Davis.

\section{Forests invaded by sudden oak death}

\section{Pathogen range and important tree hosts}

The current range of $P$. ramorum in the western US extends from newly detected infections in San Luis Obispo County on the central California coast through the coast redwood forests of Humboldt County in 
northern California, with a disjunct smaller epidemic in Curry County in southwestern Oregon. The same few epidemiologically and ecologically important tree species co-occur with varying abundance even as the forest types, fire regimes, and climate conditions change greatly across this range (Sugihara et al. 2006). The pathogen can infect dozens of species but different host species acquire different forms of the disease, so only a few host species play an important role in pathogen spread. Species that support $P$. ramorum reproduction and spread are hosts that develop infections of the leaves and/or twigs, where pathogen sporulation occurs (Davidson et al. 2011). The most important hosts for this are California bay laurel (Umbellularia californica (Hook. \& Arn.) Nutt., also called Oregon myrtlewood) and tanoak. The leaf infections that support reproduction of the pathogen are not the same types of infections that kill trees. Instead, in forests, the pathogen typically only kills species that are susceptible to developing infections on the trunk of the tree, where a large canker develops slowly under the bark and and partially or fully girdles the tree, causing it to appear to die suddenly (Davidson et al. 2003). Most species do not develop both types of infections, except tanoak and canyon live oak (Quercus chrysolepis Liebm.) (Swiecki et al. 2016). The other species that suffer lethal infections are considered dead-end hosts, because they are unable to support pathogen reproduction and spread (Davidson et al. 2005). These include coast live oak ( $Q$. agrifolia Née), Shreve's oak (Q. parvula Greene), and California black oak $(Q$. kelloggii Newb.).

The current distribution of SOD-related tree mortality reflects a few important factors governing disease emergence, including: the dispersal history and sites of introduction of the pathogen; limits to the abundance of suitable hosts; and climatic conditions conducive to reproduction and spread of the pathogen. In general, P. ramorum has invaded coast redwood (Sequoia sempervirens (D. Don) Endl.) or coast Douglas-fir (Pseudotsuga menziesii (Mirb.) Franco var. menziesii) forests and mixed-evergreen forests and woodlands dominated by bay laurel, tanoak, Pacific madrone (Arbutus menziesii Pursh), coast live oak, or other oaks. A site's fire history may also contribute to the likelihood of pathogen establishment, as suggested by early analyses (Moritz and Odion 2005), likely through successional changes to host composition following fire. In Big Sur, California, P. ramorum was found more often in stands with larger, more mature tanoak and bay laurel (Metz et al. 2012), probably because spores landing in these hosts' canopies can establish, reproduce, and spread locally through rain splash to neighboring trees (Hansen et al. 2008). Such large trees are more likely to occur with a longer interval between fires.

Uninvaded forests may be pathogen-free not because of any condition of the forest or fire history, but because the pathogen has not yet had an opportunity to invade. In both California and Oregon there are expanses of suitable habitat without the pathogen because there have not yet been dispersal events (Meentemeyer et al. 2004; Václavík et al. 2010). Instead, we have observed SOD's range expanding from a few sites of initial introduction on the central California coast, with substantial patchiness on the landscape. Through time, the pathogen tends to "fill in" an area, as it spreads locally from stand to stand (Meentemeyer et al. 2015). Longer-distance dispersal ( $>100 \mathrm{~m}$ ) and establishment of the disease in new forest stands happen through movement of infected plant material or spread of pathogen spores in large storms (Cushman and Meentemeyer 2008; Hansen et al. 2008; Mascheretti et al. 2008). This means there can be adjacent areas that have been impacted by the pathogen for differing amounts of time.

\section{Fire regime}

The average fire return interval and typical fire regime vary widely across $P$. ramorum's range in California and Oregon (Odion et al. 2004; Sugihara et al. 2006). These landscapes have a long history of lightning-ignited fires and fires ignited by dense populations of Native Americans for millennia (Stuart and Stephens 2006). Fire return intervals are not well characterized in many regions, but estimates vary from multiple fires per decade in the south to perhaps as long as a century or more between fires in the north (Lorimer et al. 2009; Stephens and Fry 2005; Stuart and Stephens 2006). For some regions, such as Big Sur, there is a poor understanding of fire history. Many areas with heavy SOD impacts also contain high human population density (e.g., the San Francisco Bay Area) while others are remote wilderness. 
Due to this variation, the effects of fire exclusion and past land-use have further complicated contemporary fire regimes and the fuels management and firefighting tactics that result.

\section{Potential SOD-fire interactions}

Bark beetle outbreaks are often cited as example systems for considering the potential effects of pathogens such as $P$. ramorum on forests and potential interactions between pathogens and other forest disturbances. How useful a comparison other systems will be depends on the biological context, or on the spatial and temporal scales, extent, and severity of the biotic disturbance (e.g. beetles) and the coincident abiotic disturbance (e.g. wildfire). That is, it is important to note how fire behavior, plant mortality, and regeneration vary across systems as the traits of both the forests and the biotic and abiotic disturbances in question also vary. For instance, in other western US forests, several studies have examined the coincident occurrence of fire in areas of previous bark beetle outbreaks and present mixed evidence for increased, neutral, or negative fire effects (Andrus et al. 2016; Hart et al. 2015; Harvey et al. 2013, 2014; Meigs et al. 2015). Should fires occur in heavily impacted areas, however, current fire behavior models do not adequately account for the mechanisms by which beetles would alter fire behavior, which include complex and temporally variable changes to live and dead fuel characteristics (Jolly et al. 2012). The consequences of interactions between SOD and fire likely differ from the outcomes of such interactions in other systems due to the distinct traits of coastal California's historical fire regimes, aspects of forest structure and composition, and the gradual, often patchy patterns of mortality and fuel accumulation caused by this disease, compared to more acute pulse disturbance events that typify insect outbreaks. A major goal of this review is to synthesize existing field-based data on SOD impacts and wildfire effects, to examine explicitly the mechanisms by which disease and fire have interacted.

\section{Forest composition matters}

The impact of $P$. ramorum on a particular forest type and the potential for these impacts to alter fire behavior depend in part on the relative abundance of host species that play different roles in the disease dynamics (Figure 2). For example, dead-end hosts like coast live oak are unlikely to experience high levels of mortality in the absence of a sporulating host like bay laurel or tanoak. When isolated sporulating hosts are surrounded in a stand by non-hosts, such as isolated tanoaks surrounded by conifers, the disease is unlikely to spread far in the short term or do any significant damage (Cobb et al. 2012b).

The species $P$. ramorum infects also differ in their responses or resistance to wildfire damage. With the exception of conifers like coast Douglas-fir and western hemlock (Tsuga heterophylla (Raf.) Sarg.), the majority of the dominant tree species (including coast redwood, bay laurel, tanoak, and oak species) in forest types infested by $P$. ramorum are capable of resprouting when aboveground stems are killed ("topkilling") or injured (with potential for epicormic re-sprouting) by fire (Del Tredici 1999; Tappeiner, McDonald, and Hughes 1986). However, each species exhibits differential resistance to top-killing due to variation in bark protection and canopy position (Sawyer et al. 1999). For instance, due to its thick bark, heavily protected meristematic tissue, and high branches coast redwood trees are less commonly killed by wildfire (Sawyer et al. 1999). Stems of understory and subcanopy species with thinner bark (such as bay laurel and tanoak), more commonly damaged by fire, instead rely more heavily on resprouting regeneration to persist following wildfire (McDonald 1983). Thus, hosts that play different roles in disease persistence and spread may also differ in fire-resistance, fire-tolerance and post-fire regeneration, also influencing the outcomes of potential SOD-fire interactions.

\section{Tree mortality increases aerial crown and downed dead woody fuels}

Forests invaded by SOD have more standing dead trees or dead and downed woody fuels compared to disease-free forests. In Big Sur, at the southern end of the pathogen's range, the basal area (summed cross-sectional area) of standing dead trees that are hosts for P. ramorum was 2.1 to 3.7 times as high in 
infested stands as the same measure observed in uninfested stands (assumed to represent background mortality rates for these species) for mixed-evergreen and redwood forest types, respectively (Metz et al. 2011). In coast redwood forests from Big Sur to Sonoma County the mean mass of tanoak coarse woody debris was approximately 10 to 100 times greater in diseased stands than disease-free stands (22.4 vs. $0.27 \mathrm{Mg} \mathrm{ha}^{-1}$ for standing snags and $11.5 \mathrm{vs} .1 .16 \mathrm{Mg} \mathrm{ha}^{-1}$ in large logs, 1,000 hr fuels) with slower rates of accumulation than with pulse disturbances such as a fire or harvesting (Cobb et al. 2012a). In the mixed-evergreen oak woodlands of the San Francisco Bay Area, there were 5.7 times as many dead coast live oak stems in areas of SOD-related mortality compared to intact stands, resulting in $1 \mathrm{~h}, 10 \mathrm{~h}$, and 100 $\mathrm{h}$ fuel masses that were nearly doubled in these plots while $1000 \mathrm{~h}$ fuels were nearly 20 times that of intact forests (Shaw et al. 2017). Douglas-fir- and redwood-dominated forests invaded by P. ramorum in Point Reyes National Seashore, just north of the San Francisco Bay area, had roughly 2.5 times the $1 \mathrm{~h}$, $10 \mathrm{~h}$, and $100 \mathrm{~h}$ fuels as healthy forests (Forrestel et al. 2015). Fuels continued to increase over the four year period of the study, such that the depth of the fuel bed in diseased stands was four times as deep as in healthy stands (Forrestel et al. 2015).

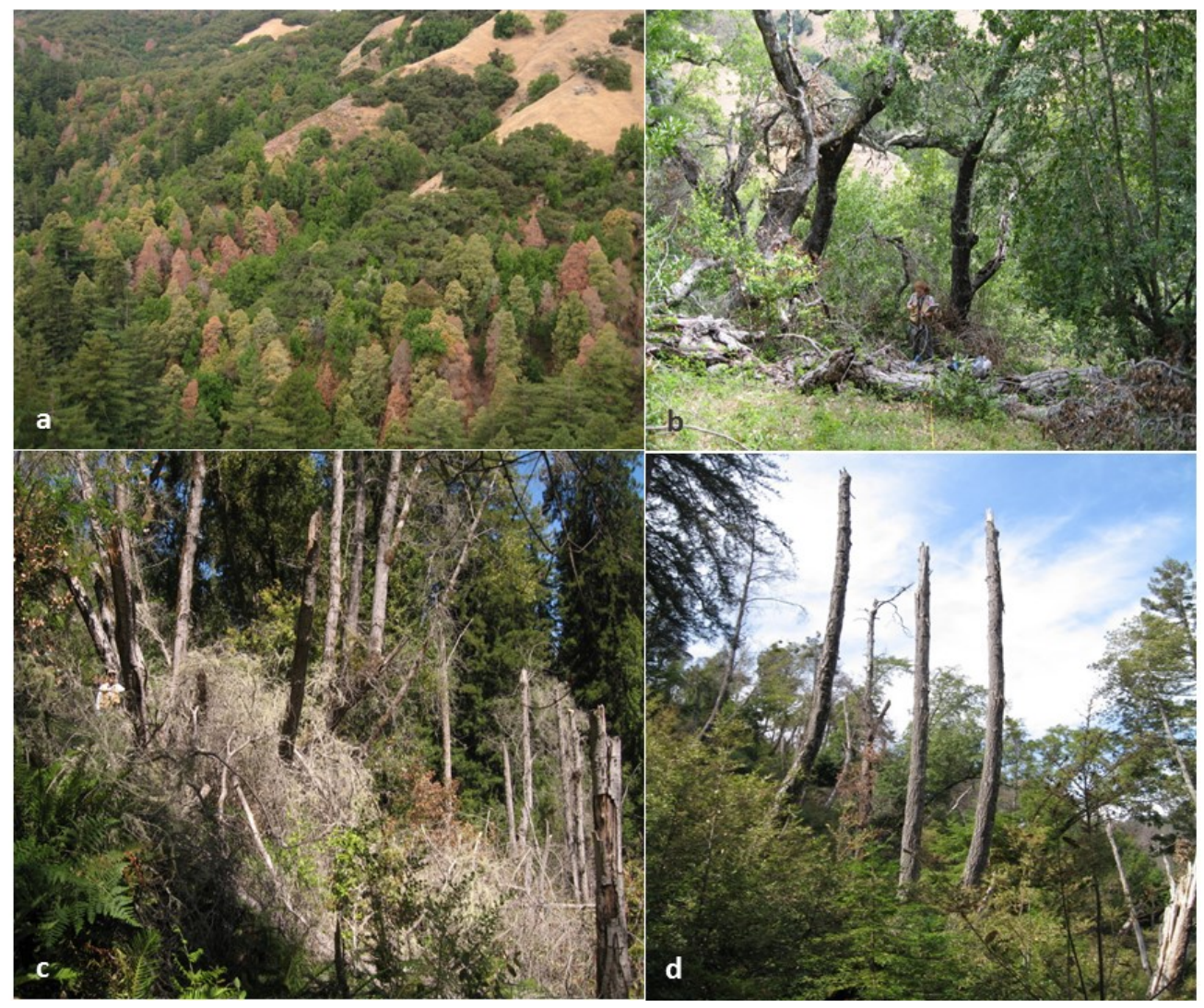

Figure 2. SOD-created fuels vary with disease stage and forest type: (a) landscape in early stages of SOD infestation, with standing dead tanoaks retaining dead foliage; (b) Mixed-evergreen forest dominated by coast live oak in late-stage of SOD infestation; (c) Mid-stage SOD infestation with impenetrable heavy fuels on the ground and many standing dead trees; (d) Late stage SOD infestation with snags and resprouting tanoak creating brushy conditions that hide ground fuels. Photos: Kerri Frangioso.

\section{Landscape heterogeneity in fuels}

Spatial and temporal variation in pathogen establishment has an important consequence for fuel development. Field studies have consistently found that SOD causes great variation in fuels across space and through time (Forrestel et al. 2015; Kuljian and Varner 2010; Metz et al. 2011, 2013; Valachovic et 
al. 2011). When trees die from SOD, it is typically the result of a multi-year development of a canker on the trunk of the tree that eventually grows large enough to girdle the tree or make the tree susceptible to attack by bark or ambrosia beetles (Rizzo, Garbelotto, and Hansen 2005). Trees appear to die suddenly, going from a green crown to one filled with dry brown leaves (Figure 2). Many trees killed by SOD retain these dry leaves and fine twigs for a year or two following death. Eventually this material begins to fall to the ground and the standing dead snag fragments and falls to the ground, leading to heavy accumulations of coarse woody debris. The timeline from infection to death to felling of all fuels is a long one, and the quantities and qualities of these fuels vary accordingly (Kuljian and Varner 2010, 2013). Stands that have recently been invaded by the pathogen may resemble healthy uninvaded stands for the first few years until trees begin dying. Once that occurs, fuels begin shifting from live canopy fuels to dead, dry, aerial fuels (leaves and twigs retained in killed tree crowns) and eventually to ladder and surface fuels as time since tree death increases. If two nearby stands were invaded by the pathogen in different years or are characterized by different species composition or microclimatic conditions, which impact pathogen spread, the fuels in those stands are likely to be at a different stage of disease progression, leading to variation across the landscape (Figure 2). The spatial variation in fuels is difficult to incorporate into fire behavior models or to map in detail for firefighting operations (Rothermel 1972).

\section{Fuel flammability differs in SOD-impacted forests}

Susceptibility to mortality by $P$. ramorum varies by species, with only a few species in any forest type contributing to dead fuel increases as a result of SOD. As canker host species like tanoak or coast live oak are killed in P. ramorum-infested stands, these species become underrepresented in live fuels and litterfall and overrepresented as dead fuels in the stand, relative to stands uninvaded by the pathogen (Cobb et al. 2012a; Cobb 2013). The species mixture constituting live and dead fuels in invaded stands thus differs from healthy stands, and fire behavior may be expected to differ accordingly because of differences in flammability among the species in these forests (Figure 2).

Selective removal of one or a few species changes the arrangement and average fuel quality in the stand. On average, the summer fire season fuel moisture content of dead tanoak leaves and twigs initially retained by a SOD-killed tree was lower than surface litter and fell to ca. 5 to $10 \%$ (dry weight basis) moisture content. Healthy tanoak leaves, in contrast, averaged ca. $80 \%$ moisture content over this same period (Kuljian and Varner 2010). Over the one to three years that SOD-killed tanoaks retain these lowmoisture fuels in their crown, laboratory burning experiments have shown there is a greater likelihood of ignition of crown fuels relative to the fireline intensity required to ignite uninfected crown leaves (Kuljian and Varner 2013). The species composition of the fuels also matters. For example, Varner et al. (2017) has found that surface litter fuel mixtures that include Douglas-fir (as a replacement for tanoak) lead to reduced flammability when compared with mixtures from communities without Douglas-fir. Selective tanoak removal by SOD mortality could change fire behavior because resulting fuels have properties that confer diminishing flammability (measured by flame height, duration of flaming, and smoldering) (Varner et al. 2017).

\section{Simulation modeling suggests fuel changes will alter fire behavior}

Two studies have used field-based fuels estimates to simulate the potential effect of SOD-related fuels on fire behavior with the BehavePlus fire modeling system. In Douglas-fir and redwood forests of Point Reyes, flame lengths tripled, spread rates increased seven-fold, and fireline intensity was predicted to be nearly 13 times higher in diseased stands relative to healthy stands (modeled using the TL5 and TL3 surface fuels models, respectively) (Forrestel et al. 2015). In northern California Douglas-fir-dominated forests, increased fuels related to SOD, particularly the accumulation of surface fuels in later stages of the epidemic, were predicted to lead to increased flame length, rates of spread, and fireline intensities relative to disease-free forests, resulting in shifts in firefighting from handcrews to a mechanized response (Valachovic et al. 2011). While fuel model SB2 seemed to represent the fuels and behavior in early stage disease plots, no existing fuels model seemed to fit the conditions of fuel accumulation in later stages of 
the disease (Valachovic et al. 2011). Both studies urged caution when using results of these simulation models because fire behavior is dependent on several other landscape and climatic factors that are difficult to model in addition to the imperfect match of existing fuels models to the complexity of SODrelated fuels. Still, the potential for SOD to increase flame length and fireline intensities combined with the build-up of large-sized surface fuels and low moisture aerial fuels may increase the transition to crown fire and make firefighting operations more complex and create the need for different tactical responses.

\section{Testing SOD-fire interactions: wildfires in Big Sur, CA}

In 2008, the Basin Complex and Chalk fires together burned 71,400 hectares in Big Sur, including more than $40 \%$ of a long-term SOD monitoring network that had been previously surveyed for tree mortality, pathogen presence, and fuel loads (Metz et al. 2011, 2012). These fires provided the opportunity to field test the potential fire-disease interactions predicted by simulations and lab studies. Questions of concern included whether SOD-related fuels would alter the risk or frequency of fires, fire intensity, and/or ecological impacts of fire in the short- or long-term. Post-fire field studies and conversations with firefighting personnel offer insight into the likely influences of SOD on wildfire.

\section{Has SOD increased the risk of fire occurrence?}

Wildland fire management is complex in the Big Sur area because of the rugged topography and limited road access, and it is difficult to compare fire suppression effectiveness to other sites in the west (Davis and Borchert 2006). Current evidence points to fires in this region having been driven by climate and ignition sources and not limited by fuels (Davis and Borchert 2006). We have limited ability to assess increased fire occurrence risk from SOD-related fuels, but the few fires in Big Sur that have occurred since invasion by $P$. ramorum support this view of fire ignition risk being primarily related to climate and limited ignition sources. A large and rare dry lightning storm in late June 2008 sparked thousands of fires across California, including the fires that became the Basin Complex Fire. In December 2013, during what should have been the rainy season but was instead unusually dry due to an intense drought, the Pfeiffer Fire (2013) burned 370 hectares after ignition from human activity. More recently, the massive 2016 Soberanes Fire (the most expensive wildfire in US history) burned 53,500 hectares after ignition by an illegal campfire.

Extreme weather events that lead to ignition may worsen under climate change (Westerling and Bryant 2007), and growing population sizes and use of wilderness areas may increase accidental or intentional ignitions by humans (Syphard et al. 2007). Additional fuels from SOD likely do not increase these risks. In fact, there was significant overlap between the footprints of the 2008 Basin Complex and the 2016 Soberanes Fires, which supports the idea that fires in this region are driven primarily by climate rather than fuel availability. Live fuels re-accumulated rapidly following the 2008 Basin Complex fire, due to the dominance of resprouting species, but there was not enough time between the fires for extensive reaccumulation of dead fuels due to SOD (Rizzo et al., unpublished data). The Soberanes Fire nevertheless resulted in extensive mandatory evacuation, significant property loss, and a protracted firefighting effort.

\section{Has SOD increased fire intensity? - Accounts from fire-fighting efforts}

Lee et al. (2009) surveyed firefighting personnel involved in suppression of the Basin Complex Fire. In many ways, their perceptions and anecdotal accounts of fire behavior matched predictions from the simulation models described above. Respondents noted longer flame lengths and increased residence times, both attributed to SOD-related mortality, and cited the intensity of the fireline as a consideration in reducing the feasibility of direct attack on the fire (Lee et al. 2010). Respondents also noted the patchiness of the fuels across the rugged topography, which contributed to cyclical increases and decreases in fire activity and difficulties predicting behavior. Large numbers of dead trees, presumably killed by SOD, were seen as falling hazards and sources of more spotting (long-distance dispersal of burning firebrands), 
which contributed to the unpredictability observed in fire spread (Lee et al. 2010). These concerns were echoed by firefighting personnel involved in the Pfeiffer Fire.

\section{Has SOD increased fire severity? - Results from the field}

The footprints of the 2008 Basin Complex and Chalk Fires burned much of a network of 280 long-term monitoring plots that had been established in 2006-07 to understand impacts of SOD on forest dynamics and diversity (Metz et al. 2011). The burned plots included both mixed evergreen and redwood-tanoak forest stands encompassing a range of disease impacts, from no pathogen invasion to intermediate and severe pathogen-related mortality (Metz et al. 2012). This provided a unique natural experiment to investigate the potential for SOD to worsen or change wildfire behavior and severity. Metz et al. (2011, 2013) used pre-fire measures of standing dead and downed woody fuels in areas with and without the disease as an estimate of disease impacts and immediate post-fire surveys for measures of burn severity. Specifically, they measured the height of scorched and consumed vegetation as a proxy for fireline intensity, the scorched or consumed tree crown volume as a measure of fire injury that might predict tree death, and coarse woody debris consumption and generation as well as damage to the litter and soil on the forest floor.

The two most important findings from this work have been the dependency of fire severity on the stage of the disease in the stand and unpredictable synergistic effects of fire and disease that include spillover damage to species that are unexpected to be impacted by fire (Metz et al. 2011, 2013). Both findings depend on understanding how fuels vary depending on the time since the disease established in a stand (described above). There was more damage to soils when there was an accumulation of coarse woody fuels on the ground (as often found in the later stages of the disease) that were capable of smoldering for long durations, affecting soils and post-fire erosion, and greater injury to tree crowns when the forest canopy was interspersed with dead trees in the early stages of the disease (Metz et al. 2011). Intermediate stages of the disease appeared to be the most hazardous for fire-disease interactions because of the complex mixture of surface, ladder and aerial fuels in various stages of fragmentation or decomposition that can connect surface fires to low tree crowns and transmit fire into the canopy (Metz et al. 2013).

The increased transmission of fire to the canopy and prolonged residence times likely contributed to unexpected interactions between disease and fire, altering patterns of tree mortality and nutrient cycling. Coast redwood is not negatively impacted by the disease (Davidson, Patterson, and Rizzo 2008) and is adapted and resilient to periodic wildfires (Stuart and Stephens 2006). However, coast redwood trees with diameter at breast height $(\mathrm{dbh})<100 \mathrm{~cm}$ experienced unexpectedly elevated mortality (measured by the percentage of live basal area that was top-killed) in SOD-infested stands, an almost $200 \%$ increase over the basal area loss due to fire in pathogen-free stands (Metz et al. 2013). The interaction between disease and fire was most severe in the middle stages of disease progression, when median and maximum char heights measured twice the heights observed in stands that were in the early or very late stage of disease. If fires increase in frequency in these forests, there may be increased redwood mortality because of the ways prolonged burning at the base of even the largest redwoods can lead to hollowing of the trunk and reduced structural integrity (Lorimer et al. 2009). In both coast redwood and mixed-evergreen forests, there was a greater fire-related loss of forest floor carbon and smaller mineral pools in diseased stands relative to disease-free stands (Cobb et al. 2016), likely due to the prolonged residence times from accumulated surface fuels and matching observations of increased soil damage with increasing coarse woody debris (Metz et al. 2011).

\section{Did wildfires reduce $P$. ramorum prevalence?}

The occurrence of the Basin Complex Fires in Big Sur decreased the prevalence of P. ramorum in burned areas; however, the pathogen was not eradicated entirely from burned regions and was recovered from some sites in the first year following the fire. Bay laurel suffered high fire-related mortality in the Basin Fire (Metz et al. 2013). Because of its important epidemiological role, such shifts in post-fire forest 
composition would be expected to influence disease dynamics (Haas et al. 2011). Individual hosts that survive a fire may serve as refugia for the pathogen or as early sites of reinvasion, however. For example, surveys conducted one and two years after the Basin Fire showed that recovery of $P$. ramorum was positively correlated with the number of pre-fire symptomatic bay trees and with post-fire survival of bay canopies (Beh et al. 2012). Heterogeneity in burn severity in the Basin Fire allowed for patchy survival of bay laurel trees, which served as inoculum reservoirs and contributed to early pathogen spread to regenerating vegetation (Beh et al. 2012). By five years post-fire, the pathogen was recovered from at least one tree in $81 \%$ of burned redwood-tanoak plots that had been infested pre-fire (Rizzo, unpublished data). Burning of infected host material has been used in eradication efforts in southwestern Oregon (Goheen et al. 2002), where the spread of $P$. ramorum out of known infection centers has been slowed but not stopped (Hansen et al. 2008). Taken together, these experiences indicate complete eradication of the pathogen due to wildfire is unlikely.

Further research is needed on how post-fire environmental conditions could affect the occurrence and spread of $P$. ramorum, which is favored by cooler, moister microclimatic conditions. Fire-related tree mortality and canopy loss in the Basin and Chalk Fires generated hotter, drier, or more exposed microclimatic conditions, though the extent of these microclimatic shifts may vary widely with fire severity (Simler, Rizzo, and Meentemeyer, unpublished data). There also has been no research on the ways prescribed fire in forests impacted by $P$. ramorum could contribute to changes in host composition or microclimate that would influence SOD dynamics.

\section{Future forest trajectories following SOD-fire interactions}

Research on compounded disturbances provides evidence that the effects of one disturbance can alter the behavior of subsequent disturbance, but the long-term effects of these disturbance interactions are currently not well understood (Johnstone et al. 2016; Turner 2010). The resilience of systems to compounded disturbances may depend strongly on both the traits of the impacted community and the nature, sequence, and extent of the interaction (Johnstone et al. 2016). For example, increased outbreaks of defoliating insects and bark beetles may kill trees, alter fuel quality, and decrease the number of sexually mature trees surviving following wildfires in a variety of forest types.

The long-term effects of the interactions between SOD and wildfire on ecosystem resilience, regeneration trajectories, and future forest structure and composition remain to be seen. Forests across the range of $P$. ramorum experience a range of fire frequencies and severities and therefore may respond differently to pathogen-related changes in fuel loading and subsequent fire behavior (Sugihara et al. 2006). However, the forested ecosystems infested by $P$. ramorum share similar species composition and are generally dominated by resprouting tree species. These species can regenerate vegetatively following mortality of aboveground stems, which may allow the individual tree to persist post-fire despite loss of the tree's aboveground structure (Figure 3). Yet, Clarke et al. (2013) have found there are limits to resprouters' post-fire persistence, which depends on the protection of belowground meristematic tissue from heating. Altered fire severity due to SOD fuels could also lead to increased injury or mortality of belowground tissue and increased levels of belowground tree mortality. Therefore, the ability to resprout may represent a strong form of ecological memory that may reduce longer-term impacts of wildfire-SOD interactions and reduce compositional differences between pre- and post-fire communities (Bond and Midgley 2001) but the resilience conferred by this memory depends on the nature or severity of novel SOD-fire interactions (Johnstone et al. 2016). 


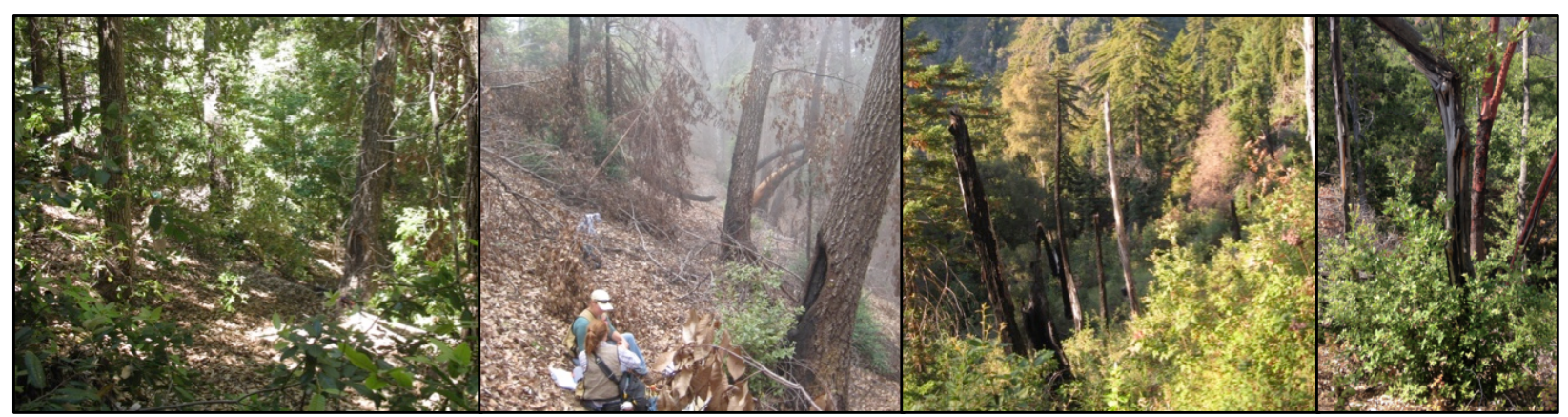

Figure 3: From left to right: (i) redwood-tanoak stand in 2006 in Big Sur, CA, infested with Phytophthora ramorum. (ii) Same stand in 2009, shortly after the 2008 Basin Fire. (iii) In 2013, after 5 years of post-fire growth; top-killed tanoak, redwood, and bay laurel trees in this same site vigorously resprouted. (iv) topkilled tanoak resprouts at a $P$. ramorum infested site in 2014. Photos courtesy of the Rizzo lab at UC Davis.

Depending on the outcomes of these potential interactions, increased aboveground and belowground tree mortality could have important consequences for post-fire regeneration trajectories. Opportunities for tree seedling and shrub recruitment are often limited by competition from surviving trees and post-fire resprouters (Clarke et al. 2013; Clarke and Knox 2009; Higgins, Flores, and Schurr 2008). Compared to uninfested burned areas, stand density and canopy cover will be reduced in areas impacted by both SOD and fire, due both to pre-fire disease and potential disease-fire interactions. This reduced competition may generate unique opportunities for tree or shrub species regenerating from seed (e.g., Ceanothus spp.) or cause shifts in plant composition or opportunities for invading plants. In particular, altered patterns of shrub recruitment could have important consequences for understory competition, forb and herb diversity, and future potential fire behavior as sites dominated by shrubs may generate a characteristically short and dense profile of fine fuels, compared to intact forests (Ottmar et al. 2007). Further, the observed post-fire differences in nutrient dynamics (Cobb et al. 2016) between SOD-impacted and disease-free sites may also alter competitive dynamics and community assembly.

\section{Management considerations}

The potential for interactions between wildfire and disease is not limited to the forests of Big Sur or the range of $P$. ramorum. Increased movement of species across the globe has caused accidental pest and pathogen introductions in many forests and the impacts of a warming climate are being felt in all sorts of ecosystem responses. Potential interactions among these disturbances depend on the specific fire regime, the biology of the pest or pathogen, and, often, the timing of these perturbations.

\section{Fuels, ignitions, and fire occurrence}

If fires in coastal forests invaded by P. ramorum are more climate- and ignition-limited than fuels-limited, the pathogen will probably not affect the likelihood of wildfire occurrence, but may significantly alter fire behavior and the success of firefighting operations, as described above. However, human activities, such as campfires, illegal camping, roadways, and development, can alter ignition risk and consequent fire occurrence in SOD-impacted systems (Syphard et al. 2007). Along the wildland-urban interface, existing firebreaks, or other sensitive areas, removing or diminishing disease-related fuels via reduction of standing snags, piling and burning, or mastication should be a consideration. A larger landscape fire management plan will be necessary to manage landscape scales and in sites with difficult access because of distance to roads, inaccessible slopes, or in protected areas (e.g., wilderness), and where such fuels reduction is not allowed by policy. The predicted future spread of SOD into dry fire-prone forests inland may press this emergent issue. 


\section{Integrating disease and fire management goals}

Potential disease-fire interactions indicate SOD- and fire-related management activities may achieve shared goals, and action plans should utilize this potential overlap. Targeted removal of bay laurel before establishment of the pathogen is recommended as a management action to reduce disease impacts in coast live oak-dominated stands, as the removal of this key sporulating host could significantly reduce oak mortality and disease spread (Swiecki and Bernhardt 2008). This disease management tool could also reduce SOD-related fuel hazard or fire severity in areas of firefighting concern, such as near structures, campgrounds, roadsides, or even along existing fire breaks. Bay removal may be feasible at only smaller scales, and we recommend this only in select stands of high conservation or aesthetic value, or in areas where dead trees may present hazards (Swiecki and Bernhardt 2013). The efficacy of this management action for disease and fire management is still being tested experimentally. Bay laurel can be particularly hard to kill (even with use of herbicides) leading to continued sporulation potential on bay laurel resprouts following treatments (Swiecki and Bernhardt 2013).

We have observed wildfire in California and fire as a management tool in Oregon to reduce local pathogen occurrence, survival, and spread, and therefore fire return intervals may influence the rates and spatial pattern of future disease impacts (Beh et al. 2012; Hansen et al. 2008). Further, though SOD may not directly alter ignition likelihood, these systems are impacted by increasing human ignitions, and fuel levels in resprouting stands recover quickly, allowing fires to spread even under shorter intervals. An example of this was the 2016 Soberanes Fire in Big Sur, California, which burned uninhibitedly into the perimeter of the previous 2008 Basin Complex Fire. Decreasing fire return intervals and/or increasing fire severity may compromise the resprouting capacity of tanok and oak trees in these systems, adding an additional pressure on populations already threatened by SOD. Resprouting species rely on stored belowground carbohydrates to fuel post-fire resprouting, and narrowing fire return intervals may not allow trees to store sufficient resources between disturbances (Clarke et al. 2013), which could lead to increased mortality in already declining oak and tanoak populations. Therefore, management of fire frequency may ultimately play an important role in the conservation of disease-impacted oak and tanoak species, beyond initial SOD-fire interactions.

\section{Acknowledgements}

We are grateful for the cooperation and support of community members, landowners, agencies and governments at the local, state and federal level, especially the community of Big Sur, CA, without whose assistance this work would have been impossible. The USDA Forest Service Pacific Southwest Research Station, USDA Forest Service State and Private Forestry, the National Science Foundation (EF-0622770) as part of the joint NSF-NIH Ecology of Infectious Disease program, and the Gordon and Betty Moore Foundation provided generous financial support for the research. We thank the many students and researchers from the Rizzo, Meentemeyer, and Varner labs for countless hours in the field and lab collecting these data. This paper is dedicated to the memory of Dr. Shannon O'Leary, whose steadfast friendship and curiosity about the natural world are greatly missed.

\section{Literature cited}

Andrus, R. A., Veblen, T. T., Harvey, B. J., and Hart, S. J. 2016. Fire severity unaffected by spruce beetle outbreak in spruce-fir forests in southwestern Colorado. Ecol. Appl. 26:700-711.

Aukema, J. E., McCullough, D. G., Von Holle, B., Liebhold, A. M., Britton, K., and Frankel, S. J. 2010. Historical accumulation of nonindigenous forest pests in the continental United States. Bioscience 60:886-897.

Beh, M. M., Metz, M. R., Frangioso, K. M., and Rizzo, D. M. 2012. The key host for an invasive forest pathogen 
also facilitates the pathogen's survival of wildfire in California forests. New Phytol. 196:1145-1154.

Bond, W. J., and Midgley, J. J. 2001. Ecology of sprouting in woody plants: the persistence niche. Trends Ecol. Evol. 16:45-51.

Clarke, P. J., and Knox, K. J. E. 2009. Trade-offs in resource allocation that favour resprouting affect the competitive ability of woody seedlings in grassy communities. J. Ecol. 97:1374-1382.

Clarke, P. J., Lawes, M. J., Midgley, J. J., Lamont, B. B., Ojeda, F., Burrows, G. E., et al. 2013. Resprouting as a key functional trait: How buds, protection and resources drive persistence after fire. New Phytol. 197:19-35.

Cobb, R. C., Chan, M. N., Meentemeyer, R. K., and Rizzo, D. M. 2012a. Common factors drive disease and coarse woody debris dynamics in forests impacted by sudden oak death. Ecosystems 15:242-255.

Cobb, R. C., Eviner, V. T., and Rizzo, D. M. 2013. Mortality and community changes drive sudden oak death impacts on litterfall and soil nitrogen cycling. New Phytol. 200:422-431.

Cobb, R. C., Filipe, J. A. N., Meentemeyer, R. K., Gilligan, C. A., and Rizzo, D. M. 2012b. Ecosystem transformation by emerging infectious disease: loss of large tanoak from California forests. J. Ecol. 100:712-722.

Cobb, R. C., Meentemeyer, R. K., and Rizzo, D. M. 2016. Wildfire and forest disease interaction lead to greater loss of soil nutrients and carbon. Oecologia. 182:265-276.

Cobb, R. C., and Rizzo, D. M. 2012. Decomposition and N cycling changes in redwood forests caused by sudden oak death. Pages 357-362 in: Proceedings of coast redwood forests in a changing California: A symposium for scientists and managers. Standiford, R. B.; Weller, T. J.; Piirto, D. D.; Stuart, J. D, tech. coords. Gen. Tech. Rep. PSW-GTR-238. Albany, CA: Pacific Southwest Research Station, Forest Service, U.S. Department of Agriculture.

Cushman, J. H., and Meentemeyer, R. K. 2008. Multi-scale patterns of human activity and the incidence of an exotic forest pathogen. J. Ecol. 96:766-776.

Davidson, J. M., Patterson, H. A., Rizzo, D.M. 2008. Sources of inoculum for Phytophthora ramorum in a redwood forest. Phytopathology 98:860-866.

Davidson, J. M., Patterson, H. A., Wickland, A. C., Fichtner, E. J., and Rizzo, D. M. 2011. Forest type influences transmission of Phytophthora ramorum in California oak woodlands. Phytopathology 101:492-501.

Davidson, J. M., Werres, S., Garbelotto, M., Hansen, E. M., and Rizzo, D. M. 2003. Sudden oak death and associated diseases caused by Phytophthora ramorum. Plant Health Prog.

Davidson, J. M., Wickland, A. C., Patterson, H. A., Falk, K. R., and Rizzo, D. M. 2005. Transmission of Phytophthora ramorum in mixed-evergreen forest in California. Phytopathology. 95:587-96.

Davis, F. W., and Borchert, M. 2006. Central coast bioregion. Pages 321-349 in: Fire in California's ecosystems, eds. N. G. Sugihara, J W Van Wagtendonk, K E Shaffer, J Fites-Kauffman, and A E Thode. Berkeley, CA:

University of California Press.

Del Tredici, P. 1999. Redwood burls: immortality underground. Arnoldia 59:14-22.

Ellison, A. M., Bank, M. S., Clinton, B. D., Colburn, E. A., Elliott, K., Ford, C. R., et al. 2005. Loss of foundation species: consequences for the structure and dynamics of forested ecosystems. Front. Ecol. Environ. 3:479-486.

Forrestel, A. B., Ramage, B. S., Moody, T., Moritz, M. A., and Stephens, S. L. 2015. Disease, fuels and potential fire behavior: impacts of sudden oak death in two coastal California forest types. For. Ecol. Manage. 348:23-30.

Goheen, E. M., Hansen, E. M., Kanaskie, A., McWilliams, M. G., Osterbauer, N., and Sutton, W. 2002. Sudden oak death caused by Phytophthora ramorum in Oregon. Plant Dis. 86:441. 
Haas, S., Hooten, M., Rizzo, D. M., and Meentemeyer, R. K. 2011. Forest species diversity reduces disease risk in a generalist plant pathogen invasion. Ecol. Lett. 14:1108-1116.

Hansen, E. M., Kanaskie, A., Prospero, S., McWilliams, M., Goheen, E. M., Osterbauer, N., et al. 2008. Epidemiology of Phytophthora ramorum in Oregon tanoak forests. Can. J. For. Res. 38:1133-1143.

Hart, S. J., Schoennagel, T., Veblen, T. T., and Chapman, T. B. 2015. Area burned in the western United States is unaffected by recent mountain pine beetle outbreaks. Proc. Natl. Acad. Sci. U. S. A. 112:4375-80.

Harvey, B. J., Donato, D. C., Romme, W. H., and Turner, M. G. 2014. Fire severity and tree regeneration following bark beetle outbreaks: the role of outbreak stage and burning conditions. Ecol. Appl. 24:1608-1625.

Harvey, B. J., Donato, D. C., Romme, W. H., and Turner, M. G. 2013. Influence of recent bark beetle outbreak on fire severity and postfire tree regeneration in montane Douglas-fir forests. Ecology. 94:2475-2486.

Higgins, S. I., Flores, O., and Schurr, F. M. 2008. Costs of persistence and the spread of competing seeders and sprouters. J. Ecol. 96:679-686.

Johnstone, J. F., Allen, C. D., Franklin, J. F., Frelich, L. E., Harvey, B. J., Higuera, P. E., et al. 2016. Changing disturbance regimes, ecological memory, and forest resilience. Front. Ecol. Environ. 14:369-378.

Jolly, W. M., Parsons, R., Varner, J. M., Butler, B. W., Ryan, K. C., and Gucker, C. L. 2012. Do mountain pine beetle outbreaks change the probability of active crown fire in lodgepole pine forests? Comment. Ecology. 93:9415-50.

Kuljian, H., and Varner, J. M. 2013. Foliar consumption across a sudden oak death chronosequence in laboratory fires. Fire Ecol. 9:33-44.

Kuljian, H., and Varner, J. M. 2010. The effects of sudden oak death on foliar moisture content and crown fire potential in tanoak. For. Ecol. Manage. 259:2103-2110.

Lee, C., Valachovic, Y., Frankel, S., and Palmieri, K. 2010. Sudden oak death mortality and fire: Lessons from the Basin Complex. Pages 271-279 in: Proceedings of the Sudden Oak Death Fourth Science Symposium,Santa Cruz, CA. S. J. Frankel; J. T. Kliejunas; K. M. Palmieri, tech. coords. Gen. Tech. Rep. PSW-GTR-229. Albany, CA. Pacific Southwest Research Station, Forest Service, U.S. Department of Agriculture.

Lorimer, C. G., Porter, D. J., Madej, M. A., Stuart, J. D., Veirs, S. D., Norman, S. P., et al. 2009. Presettlement and modern disturbance regimes in coast redwood forests: Implications for the conservation of old-growth stands. For. Ecol. Manage. 258:1038-1054.

Mascheretti, S., Croucher, P. J. P., Vettraino, A., Prospero, S., and Garbelotto, M. 2008. Reconstruction of the Sudden Oak Death epidemic in California through microsatellite analysis of the pathogen Phytophthora ramorum. Mol. Ecol. 17:2755-68.

McDonald, P. M. 1983. Local volume tables for Pacific madrone, tanoak, and California black oak in north-central California. US Dept. Agric. For. Serv. Pacific Southwest For. Range Exp. Stn. 362.

Meentemeyer, R. K., Dorning, M. A., Vogler, J. B., Schmidt, D., and Garbelotto, M. 2015. Citizen science helps predict risk of emerging infectious disease. Front. Ecol. Environ. 13:189-194.

Meentemeyer, R., Rizzo, D., Mark, W., and Lotz, E. 2004. Mapping the risk of establishment and spread of sudden oak death in California. For. Ecol. Manage. 200:195-214.

Meigs, G. W., Campbell, J. L., Zald, H. S. J., Bailey, J. D., Shaw, D. C., and Kennedy, R. E. 2015. Does wildfire likelihood increase following insect outbreaks in conifer forests? Ecosphere 6:art118. 
Metz, M. R., Frangioso, K. M., Meentemeyer, R. K., and Rizzo, D. M. 2011. Interacting disturbances: wildfire severity affected by stage of forest disease invasion. Ecol. Appl. 21:313-320.

Metz, M. R., Frangioso, K. M., Wickland, A. C., Meentemeyer, R. K., and Rizzo, D. M. 2012. An emergent disease causes directional changes in forest species composition in coastal California forests. Ecosphere 3:article86.

Metz, M. R., Varner, J. M., Frangioso, K. M., Meentemeyer, R. K., and Rizzo, D. M. 2013. Unexpected redwood mortality from synergies between wildfire and an emerging infectious disease. Ecology 94:2152-2159.

Moritz, M. A., and Odion, D. C. 2005. Examining the strength and possible causes of the relationship between fire history and sudden oak death. Oecologia 144:106-14.

Odion, D. C., Frost, E. J., Strittholt, J. R., Jiang, H., Dellasala, D. A., and Moritz, M. A. 2004. Patterns of fire severity and forest conditions in the western Klamath Mountains, California. Conserv. Biol. 18:927-936.

Ottmar, R. D., Sandberg, D. V, Riccardi, C. L., and Prichard, S. J. 2007. An overview of the fuel characteristic classification system - quantifying, classifying, and creating fuelbeds for resource planning. Can. J. For. Res. 37:2383-2393.

Rizzo, D. M., and Garbelotto, M. 2003. Sudden oak death: endangering California and Oregon forest ecosystems. Front. Ecol. Environ. 1:197-204.

Rizzo, D. M., Garbelotto, M., and Hansen, E. A. 2005. Phytophthora ramorum: integrative research and management of an emerging pathogen in California and Oregon forests. Annu. Rev. Phytopathol. 43:309-335.

Rothermel, R. C. 1972. A mathematical model for predicting fire spread in wild land fuels. USDA For. Serv. Res. Pap. INT-115:40.

Sawyer, J. O., Sillett, S. C., Libby, W. J., Dawson, T. E., Popenoe, J. H., Largent, D. L., et al. 1999. Redwood trees, communities, and ecosystems: a closer look. Pages 18-118 in: The redwood forest: history, ecology, and conservation of the coast redwoods, ed. R. M. Noss. Washington, DC: Island Press.

Shaw, D. C., Woolley, T., Kelsey, R. G., McPherson, B. A., Westlind, D., Wood, D. L., et al. 2017. Surface fuels in recent Phytophthora ramorum created gaps and adjacent intact Quercus agrifolia forests, East Bay Regional Parks, California, USA. For. Ecol. Manage. 384:331-338.

Steel, Z. L., Safford, H. D., and Viers, J. H. 2015. The fire frequency-severity relationship and the legacy of fire suppression in California forests. Ecosphere. 6:8.

Stephens, S. L., and Fry, D. L. 2005. Fire history in coast redwood stands in the northeastern Santa Cruz mountains, California. Fire Ecol. 1:2-19.

Stephens, S. L., and Ruth, L. W. 2005. Federal forest-fire policy in the United States. Ecol. Appl. 15:532-542.

Stuart, J. D., and Stephens, S. L. 2006. North Coast Bioregion. Pages 147-169 in: Fire in California's ecosystems, eds. N.G. Sugihara, J.W. Wagtendonk, K.E. Shaffer, J. Fites-Kaufman, and A.E. Thode. University of California Press.

Sugihara, N. G., Van Wagtendonk, J. W., Shaffer, K. E., Fites-Kauffman, J., and Thode, A. E. 2006. Fire in California's ecosystems. Berkeley, CA: University of California Press.

Swiecki, T. J., Bernhardt, E. A. 2013. A reference manual for managing sudden oak death in California. Gen. Tech. Rep. PSW-GTR-242. Albany, CA. U.S. Department of Agriculture, Forest Service, Pacific Southwest Research Station. 129 p. 
Swiecki, T. J., Bernhardt, E. A., Aram, K., Rizzo, D. M., Kasuga, T., and Bui, M. 2016. Phytophthora ramorum causes cryptic bole cankers in canyon live oak. Plant Health Prog. 17:20-26.

Swiecki, T. J., Bernhardt, E. 2008. Increasing distance from California bay reduces the risk and severity of Phytophthora ramorum canker in coast live oak. Pages 181-194 in: Proceedings of the sudden oak death third science symposium. Frankel, S. J., Kliejunas, J. T., Palmieri, K. M., tech. coords. Gen. Tech. Rep. PSW-GTR-214. Albany, CA. Pacific Southwest Research Station, Forest Service, U.S. Department of Agriculture.

Syphard, A. D., Radeloff, V. C., Keeley, J. E., Hawbaker, T. J., Clayton, M. K., Stewart, S. I., et al. 2007. Human influence on California fire regimes. Ecol. Appl. 17:1388-1402.

Tappeiner, J. C., McDonald, P. M., and Hughes, T. F. 1986. Survival of tanoak (Lithocarpus densiflorus) and Pacific madrone (Arbutus menziesii) seedlings in forests of southwestern Oregon. New For. 1:43-55.

Turner, M. G. 2010. Disturbance and landscape dynamics in a changing world. Ecology 91:2833-2849.

Václavík, T., Kanaskie, A., Hansen, E. M., Ohmann, J. L., and Meentemeyer, R. K. 2010. Predicting potential and actual distribution of sudden oak death in Oregon: prioritizing landscape contexts for early detection and eradication of disease outbreaks. For. Ecol. Manage. 260:1026-1035.

Valachovic, Y., Lee, C. A., Scanlon, H., Varner, J. M., Glebocki, R., Graham, B. D., et al. 2011. Sudden oak death caused changes to surface fuel loading and potential fire behavior in Douglas-fir-tanoak forests. For. Ecol. Manag. 261:1973-1986.

Varner, J. M., Kuljian, H. G., and Kreye, J. K. 2017. Fires without tanoak: the effect of a non-native disease on future community flammability. Biol. Invasions 19:2307-2317.

Westerling, A. L., and Bryant, B. P. 2007. Climate change and wildfire in California. Clim. Change 87:S231-S249.

Westerling, A. L., Hidalgo, H. G., Cayan, D. R., and Swetnam, T. W. 2006. Warming and earlier spring increase western U.S. forest wildfire activity. Science 313:940-943. 